\title{
Individualization factors of students' physical education at modern stage of its realization
}

\author{
Druz V.A. ${ }^{1}$, Iermakov S.S. ${ }^{2}$, Artemyeva G.P. ${ }^{1}$, Puhach Y.I. ${ }^{1}$, Muszkieta R. ${ }^{2}$ \\ ${ }^{1}$ Kharkiv State Academy of Physical Culture, Ukraine \\ ${ }^{2}$ Uniwersytet Mikołaja Kopernika w Toruniu, Poland.
}

\begin{abstract}
Purpose:

determination of main conditions for complying individual potentials of physical condition and students' physical fitness for practicing appropriate kind of sports.

Material: $\quad$ In the research students attending sport circles participated $(n=960)$. Sport qualification of the participants was in the range from beginners to international masters of sports. The contingent of the tested consisted of different age groups and sport specializations.

Results: $\quad$ for satisfaction of students' individual interests to definite kinds of sports it is necessary to have professional graphs of motor functioning in sports and ergo-graphic characteristic of competition exercises. Students shall have information about their physical condition and physical fitness. Besides, it is necessary to have the data about students' current physical condition, which determines students' workability. Passport data about medium of motor functioning and individual's physical potentials permit to find adequacy of combining and success of object-medium interaction. It results in enthusiasm in practicing certain kind of sports.

Conclusions: The presence of adequate compliance between determined analytical links of physiological processes of individual's adaptive behavior and requirements to the chosen medium of sport functioning permits to maximally effectively solve the problems of students' physical education's individualization.

Keywords: professional graph, ergo-graphic recording, motor, energy, static, student.
\end{abstract}

\section{Introduction}

The problem of students' physical education at modern stage of its re-organization implies realization of individual approach, which would consider characteristics of physical condition, initial fitness, interest to definite motor functioning and degree of its importance understanding. In each age period these tasks have own specific aspects of solution. In all cases it is necessary to determine compliance between demand in motor functioning and possibility of its satisfaction with definite motor actions [1, 2, 3].

Solution of problems of students' physical education is shown in some other directions:

- Study of students' professional-technical maturity [25];

- Study of students' attitude to physical activity and their intentions to be physically active [26, 33, 38];

- Study of health and physical education teacher's in students' training [34, 37];

- Influence of physical exercises on law faculty students' psychic health [39];

- Analysis of students' psychic health in globalized world [27, 28];

- Influence of internet and computer habits on students' health [22, 35];

- Students' leisure motor activity [31];

- Substantiation of pedagogic technology of disabled students' physical education [21];

- Sport and health related competition activity [24, 32, 36];

- Simulation of students' sport functioning [23, 29, 30]. Solution of the mentioned tasks require consideration

(c) Druz V.A., lermakov S.S., Artemyeva G.P.,

Puhach Y.I., Cieślicka M. , 2017

doi:10.15561/20755279.2017.0102 individual physical condition (biological age), which, to large extent, differs from chronological age. Special aspects of individual physical growth determine bent and succession of certain motor functioning's specificities. On the base of these specificities professional graphs of existing and appearing kinds of sport activity shall be created. With such approach age characteristics of physical condition shall be considered, as well as classification of fulfilled physical load's heaviness: by its intensity, by qualitative orientation of the fulfilled motor activity [4]. Assessment of the fulfilled physical load's feasibility requires ergo-graphic analysis. With it, it is necessary to consider that physical load's feasibility is determined by current functional state of an individual. All mentioned requirements for individual approach realization in physical education building is based on mean static indicators, which do not permit to ensure its individualization.

The purpose of the research is to solve the problem of individualization of students' physical potentials assessment. It gives rise to a group of tasks to be solved for re-organization of existing physical education system.

\section{Material and methods}

Participants: students from different Kharkov HEEs, attending sport circles' trainings, participated in the researches. Sport qualification of the participants was in the range from beginners to international masters of sports. The contingent of the tested consisted of different age groups and sport specializations. Total quantity of participants was 960 persons.

Organization of the research: the materials for the research were collected during 2010-2013, in the period of functioning of Non-Olympic and professional sports 
scientific-research institute.

The tasks of the research include:

- Determination of individual's age;

- Building of professional graphs for appropriate kinds of sport functioning;

- Ergo-graphic analysis of appropriate actions in the studied kind of sport functioning;

- Working out of organism potentials’ assessment, as well as determination of certain motor functioning kind's feasibility by dynamic of changes in organism's potentials;

- Working out of assessment of preferable motor functioning qualitative structure;

- Determination of optimal individual regime of the offered physical load.

Studies in these directions are rather fragmentary. It rather complicates formation of holistic idea about individual criteria for assessment of norm and functional optimum of organism's adaptation behavior. In such cases the used research methods are based on mean-statistical characteristics of population norm of physical condition. These norms have exhausted their solving potentials for them to be applied in individual assessment of organism's adaptation potentials. It means that it is necessary to find the ways how to solve the mentioned problems. In solution of each of the set task there are a lot of approaches. It brings to demand in general principles, determining behavioral dynamic of the studied processes. For solution of the mentioned tasks in the fulfilled works the following methods were used:

- Dynamic analogy [5];

- Theory of similarity and dimension [6];

- Analysis of empiric data in attribute semantic spaces [7];

- Mathematical modeling [8, 9].

The following bio-medical methods were used:

- Clinical anthropometry [10];

- Modeling of biological age assessment [11];

- BP indicators by orthostatic test of N.Ye. Teslenko [12];

- Standard tests for physical fitness and motor qualities. For assessment bio-mechanical characteristics the following was applied:

- Video-recording of the studied movement;

- Laws of mechanics, determining sportsman's body mass center traveling in supported and unsupported movement.

\section{Results of the research}

Understanding of analogy determines general character of regularities in different fields of knowledge. At present it permits to comprehensively use them and transfer in the conducted researches in the field of physical culture and sports. One of the most urgent problems in any professional field is clear definition of professional graph and ergo-graphic characteristic of its motor component. Solution of this problem is especially acute for theory of physical culture and sports. The first studies in this direction were made by I.M. Sechenov in
1964. In the fulfilled ergo-graphic studies of arm's work he found dependence of workability reduction on duration and intensity of the fulfilled work. However this work had descriptive character. More profound analysis was practically impossible, because up to the middle of $19^{\text {th }}$ century the conception "energy" was vague.

Characteristic of term "Energy" was based on its translation from Greek and meant power, value or efficiency of something. "Energy" was defined so in the first edition of British encyclopedia, published in 1771 . In $1783 \mathrm{~J}$. Watt introduces the unit of work, expressed in horse power. In $19^{\text {th }}$ century conceptions of kinetic and potential energy appear; laws of one energy kind transformation to other are found; ways of energy description in particular cases are determined; energy starts to be applied to human physical functioning and to its motor component. Concept of human or animals' potential energy still remained undefined and could not be measured [17].

In existing studies of motor functioning in different kinds of sports the most attention is paid to kinematic energy consumption. It is explained by feasibility of its measurement, providing body mass and velocity of its traveling are known.

According to scope of the consumed work, for transferring definite quantity of kinematic energy, their correlation permits to connect the values of kinematic energy $1 / 2 m v^{2}$ and fulfilled work FS. From this relation $1 / 2 m v^{2}=\mathrm{FS}$ it is possible to determine the force, manifested at certain segments of distance or the structure of the fulfilled movement. Determination of potential energy consumption with fulfillment static work is not possible with the help of the above mentioned expression, because there is no velocity value and indicators of body movement under impacting force.

Static efforts require great consumption of potential energy. It is necessary to consider that in structure of any movement there is static tension. This tension determines working posture. Then, consideration of potential energy consumption in physical work (when composing its ergographic description) is a necessary component.

Potential energy is directly connected with power or speed of work fulfillment. If to mean intensity of muscular tension, it is important to know the value of muscular effort and the period of its acting. These characteristics can be measured and controlled. With the help of dynamometer and stop-watch it is possible to find impulse of force $\left(\mathrm{F}^{*} \mathrm{t}\right)$.

In step-by-step method of force measurement it is possible to make a sequence of force impulse with every correlation of unbending angle between appropriate biokinematic links. Such measurements of force impulse in respect to unbending angle carry two informational characteristics:

1) Position of bio-kinematic links in respect to each other (to be measured by angle between them - $\phi$ ); value of effort with every observed position (F);

2) Period of its preservation ( $t$ ), permitting to determine force impulse $(\mathrm{Ft})$.

Consequent measurement of maximal effort (with 
fixed position between connected bio-kinematic links) and ranging of their values (with uniform increment of unbending angle) permitted to find law of effort's increment at unbending angle of joint.

This value points at velocity of maximal force increment at unbending angle $(d F / d \varphi)$. In polar coordinates system it is logarithmic spiral. Characteristic aspect of this dependence's individual features is flexion of logarithmic dependence, which does not change with every current state. The changes in the state of fatigue are registered only in force. Increment $(d F / d \varphi)$ in all cases does not change. The same dependence is noticed with velocity of this dependence growing in time $(d F / d \varphi)$. The described dependence is shown in fig. 1.

Determination of time of muscular tension duration (force impulse in every fixed position of bio-kinematic pair) was fulfilled with its different value in respect to maximum. Velocity of potential energy consumption in respect to duration of muscular tension is in exponential dependence. This manifests in different physiological processes. Its individual features are noticed only in coefficient of exponent's flexion.

Such dependence of force impulse behavior permits to find its highest value with definite force of static muscular tension. Graphically it is shown in fig. 2.

Analysis of the received dependence (see fig.2) permits

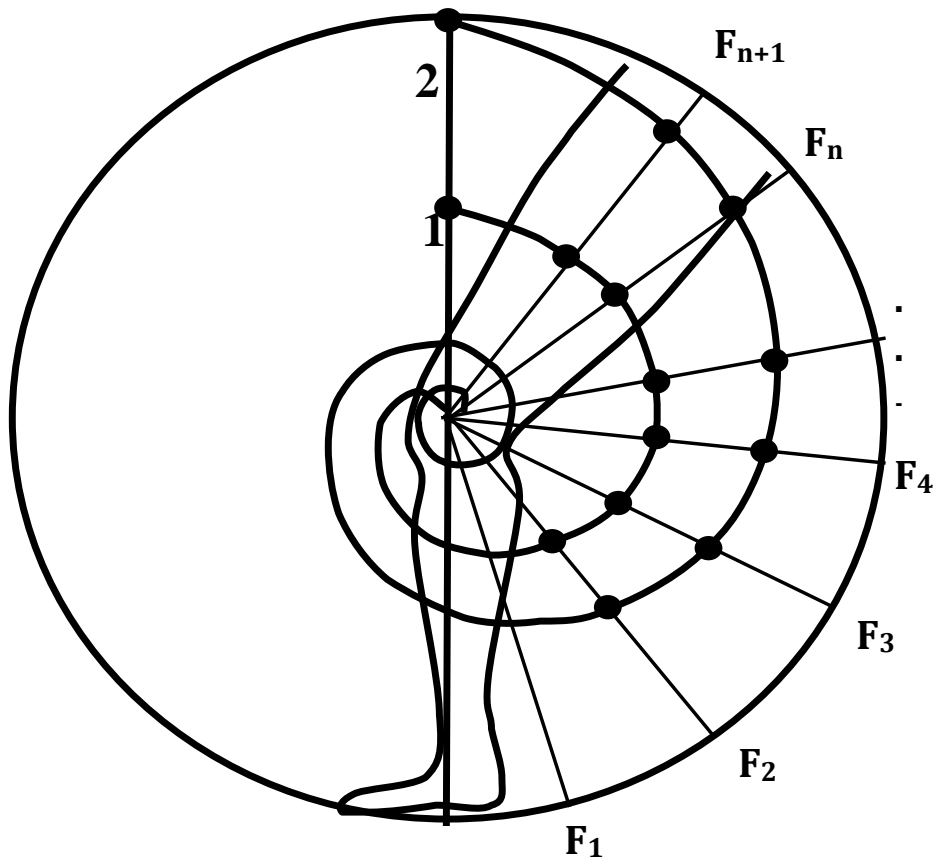

Fig.1. Graphic picture of static effort change $(\mathrm{dF} / \mathrm{d} \varphi)$ depending on unbending angle in joint. Note: 1 . Logarithmic spiral of change $(\mathrm{dF} / \mathrm{d} \varphi)$ after intensive training. 2. Logarithmic spiral of change $(\mathrm{dF} / \mathrm{d} \varphi)$ with sportsman's high workability.

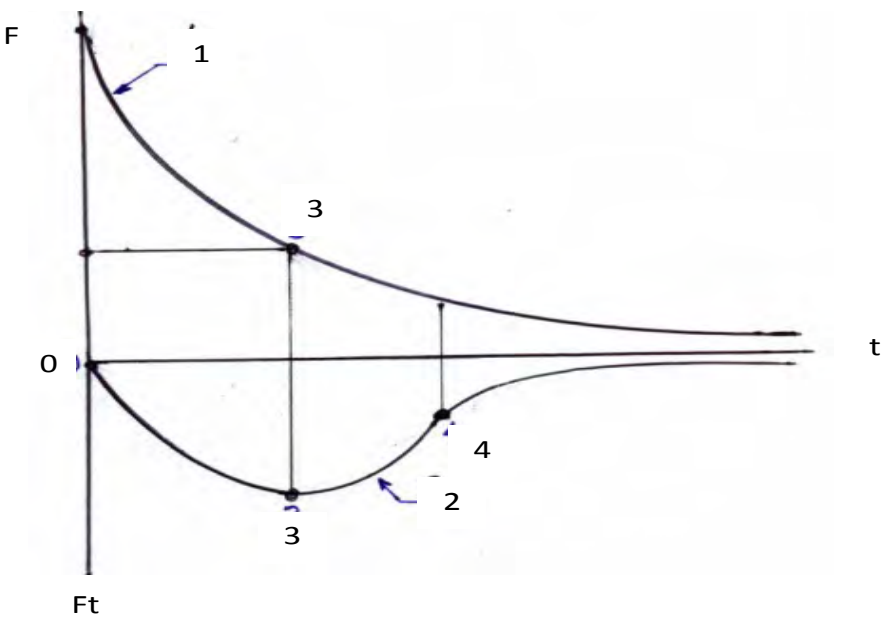

Fig.2. Graphic picture of force value dependence on intensity of impulse, generating appropriate quantity of movements. Notes: 1. Dependence curve of static tension's intensity and duration of its conservation. 2. Curve of force impulse under different intensity of static tension. 3. Graph points corresponding o maximal force impulse and tension intensity. 4. Flex point on curve 2 . Value $1 / \mathrm{e} \approx 1 / 2.72$, where e $=2.718$. 
to find that the most optimal regime of static tension (with which maximal impulse of force is observed) corresponds to force 1/e from its maximal manifestation (as on the moment of sportsman's physical condition).

With it force impulse in static tension contains maximal quantity of movement, which can be transferred to body. Maximal force with static tension I function of state and taken as "one". With physical workability weakening the value of maximum reduces. It reflects consumption of potential energy.

In fig. 1 there are two logarithmic spirals, crossing radii of force vectors. This force is manifested under different angles of bio-links' unbending. If to observe consequent reduction of physical workability then, in respect to every state, it would be possible to obtain cross point of appropriate logarithmic spiral with radius of force vector. The ranged sequence of these points will compose logarithmic sequence of workability potential's weakening. Its graph completely coincides with picture in fig.2. Individual aspects of these regularities are noticed only in coefficients, reflecting curvatures' flexion.

The mentioned regularity and "function of state" is observed in all directions of vectors radii. In this case for control of current physical condition it would be quite enough to determine the character of behavior of ranged force change sequence in different physical condition. It permits (by single measurement with fixed unbending angle between bio-kinematic pair of links) to find sportsman's current condition. The determined regularity was tested in researches of Van Sign Ny [18] and a number of other works [1-3].

The described regularity of "function of state" changes actually reflects potential energy consumption, resulted from fulfilled work and static tension. Loss of potential energy reflects organism's condition. This loss is an indicator of current workability wakening or fatigue. Determination of current maximal applied force (by corresponding vector) permits to determine degree of fatigue in the given bio-kinematic link. Such methodic permits to find the share of appropriate total bio-kinematic structure's links. It is purposeful to realize in the following conditions: when finding reasons of standard motor actions' technical violations; in optimal regime of muscular group in holistic dynamic stereotype of the fulfilled movement.

For determination integral indicator of general fatigue it is purposeful to use single dynamometric static tension, related to its maximal indication:

$$
F_{i} / F_{\max }=K,
$$

where $F_{i}$ is force as the moment of its measurement; $\mathrm{F}_{\max }$ - force, demonstrated by sportsman in his the most workable condition and taken as a criterion for comparison; $\mathrm{K}$ - indicator of workability weakening.

Exponential character is a specific feature of coefficient $\mathrm{K}$ behavior. It implies that one and the same increment of function correspond to argument increment one and the same times. When argument changes by the law of geometrical progression, function will change by the law of arithmetical sequence. Actually, this function is a foundational one in organization of biological, social and physical phenomena [19].

The found analytical connection between endurance and quickness substantially changes the methods of fatigue's study. These methods permit to realize the following: register individual aspects of the process; consider its qualitative characteristics and determine optimal load for achieving maximally possible volume of work to be fulfilled with the given intensity. When making ergo-graphic passport of sportsman's motor functioning this regularity permits to restore complete structure of reaction to different intensity loads by value back strength.

In researches of different run distances this regularity permits to find consumption of energy for static forces, directed at keeping working posture. In this case by result of standard static force (by standard plio-metric exercise) energy consumption for certain distance is found. From its value kinetic energy, spent for distance overcoming, is deducted. The received difference reflects its consumption for working posture static tension in work's fulfillment. Such methodic is presented for the first time. Its application opens new spectrum of researches, which earlier could not be realized.

\section{Discussion}

Complete solution of physical education's individualization problem is possible only when determination of univocalindividualbent'scorrespondence to motor functioning specificities and optimal medium is possible. Characteristic of medium can be measured rather accurately. Measurement of individual's potentials for assessment of his compliance with medium is also relatively solved. At present time there is no unified passport, which would contain: physical condition, degree of individual's bent to motor functioning specifics; his readiness for fulfillment of task with the set complexity and assessment of current condition.

As far as there is a demand in professional graph of every sport activity, it is necessary to make professional record of individual fitness for appropriate kind of physical functioning.

For this purpose characteristics of physical progressing as biological maturity indicator are required. Specificity of motor functioning is determined by shares of motor qualities. In this case shares' correlation of motor qualities (motor abilities and motor attributes), which determine individual motor potentials, is required in professional graph. In the whole, available at present time works in the field of physical culture and sports theory permit to practically solve this problem [13].

Ergo-graphic analysis of motor functioning was rather difficult because there were no methodic for determination of potential energy level (or reserve). Assessment of only kinetic energy did not permit to build ergo-graph of movement completely. It eliminated its value in the whole. The reason was that any motor action bears static 
tension and kinematic characteristics, reflecting traveling of body bio-kinematic links. The consumed kinetic energy is found rather simply, if to know the mass of body and its velocity. But consumption of potential energy for keeping body posture was difficult to be found. It made impossible to construct general picture of energy consumption, required for definite motor action.

This task became solvable owing to finding of regularity of force at unbending angle between appropriate bio-kinematic links of total kinematic chain of body. Determination of physical force indicators (static tension, kinematic of body links' traveling) opened wider opportunities for researches in sports, especially in cyclic kinds.

Assessment of consumed potential energy for muscular tension permits to control individual's current condition and determine his current fatigue (workability). Owing to video recording current workability can be registered without contact at any distance, feasible for visual control. The main idea of such control is that measurement of decelerating dynamic of bending angle (or unbending angle between bio-kinematic pair in plio-metric motor actions) characterizes the progress of current fatigue [14].

The worked out methods of composing individual characteristic of motor functioning qualitative structure became possible owing to implementation attribute semantic spaces in scientific research practice. In these spaces there is single measure of the used attributes' comparison. The created on his base model characteristics of the best sportsmen permit to purposefully select the closest by qualitative correspondence body structures of sportsmen-beginners [7].

Computer modeling of movements' kinematic permits to enter individual weigh-height data, bio-kinematic links' masses and their gravity centers. Such approach permits to reproduce technique of movements with complex coordination. It changes practice of sportsman's technical training rather substantially.

The problem of current express control over organism's functional state can be solved because there are many new methods of research. Of special importance are: modern methods of video recording; computer programs of video-records' processing; the found laws of organism's reactions to endured physical load.

Substantial contribution in physical training individualization and determination of different motor aptitude was made by comprehensive researches of human and animals organisms' morphological and functional systems during all history of science.

Demands of social progress and differentiation of industry deepened knowledge in appropriate fields. It resulted in development specific terminology. Then, advanced branch lost need in further deepening of knowledge, because they exceeded the frames of social demands. Need in other field of knowledge developed in the same order, but gave birth to other terminology. It complicated understanding their similarities. With certain periodic character of differentiated knowledge spheres' development there appeared demand in integration of their achievements. Such integration has certain limits of their generalization, but always substantially contributed in further deepening of knowledge. Just these periods of scientific knowledge development can be estimated as periods of synchronization of inter-conditioned researches and emersion of agreed scientific terminology [15].

Knowledge differentiation and integration processes have reproducible periodization at all levels of selforganization of inter-conditioned relations. It can be presented as frequency characteristic of the required process. The volume of fulfilled scientific knowledge differentiation and integration can be characterized as their amplitude oscillation in each of their development periods. With accumulation of knowledge certain volume and qualitative orientation there appears possibility to find the laws of this process progressing.

The most expressively this process was characterized by G. Bernal,, who said that "In science more than in any other human institute it is necessary to study the past for understanding of the present and domination over the nature in the future” [20].

Of not less importance, in this respect, is necessary accumulation of knowledge about the past for understanding it in the present [16]. Such waves of knowledge integration can be noticed in every sphere of knowledge and their interdisciplinary combinations. Long lasted struggle between vitalist and mechanistic approaches to theory of development resulted in understanding unanimity of material world development laws and then in general.

In biological field of knowledge formation of system was based on purely anatomic classification principles. Further formation of this concept presented system as a complex of inter-conditioned relations, directed at receiving final result. Their opposition ended by combining. It permitted to regard the process of development as single morphological functional interaction, resulted in organic genesis in developing “autonomous system”. Theory about unclear multitudes permitted to finalize general theory of systems. In its turn it resulted in successful solution of many tasks. It permitted to find mechanisms, explaining restriction of developing systems' complexity; reasons of emersion of functional activity differentiation; to solve the problem of paradox of development.

\section{Conclusions}

Appropriate video recording means, computers, software permitted to fulfill processing of received sport data more qualitatively. It permitted to find analytical regularities and to use video recording processing results in actual scientific researches. Such regularities are practical tool in organization of training process, control over competition performances and their further analysis.

Realization of such control implies corresponding training of coach personnel and certain logistic. Control of fatigue dynamic by change of bio-kinematic links' movements makes possible to solve this task in real time. However, with complete presence of the above mentioned 
opportunities a coach can not ensure fulfillment of all scope of possible work.

In modern training process there exists registration of sportsman's individual features and his current condition. For this purpose specialist is required, who will analyze results of video records' computer processing.

Solution of these tasks requires training specialists for ensuring scientific-technical maintenance of training and competition processes. It implies new specialization for ensuring scientific technical maintenance and control over dynamic of human functional state. Training of such specialists is dictated by need in monitoring of human current state in different branches of industrial functioning, medicine, sports and rehabilitation medicine.

\section{Conflict of interests}

The author declares that there is no conflict of interests.

\section{References:}

1. Azhippo AIu, Puhach YI, Zhernovnikova IaV. Problema opredeleniia biologicheskogo vozrasta $\mathrm{V}$ sisteme ocenki fizicheskogo razvitiia i fizicheskoj diagnostiki konstitucional'nykh zabolevanij [The problem of biological age determination insystem of physical condition and physical diagnostic of constitutional diseases system]. Slobozhans'kij naukovo-sportivnij visnik, 2015;3 (47):7-12. (in Russian)

2. Puhach YI. Vliianie individual'noj normy fizicheskogo sostoianiia i zony funkcional'nogo optimuma na rabotu $\mathrm{v}$ ekstremal'nykh usloviiakh ee vypolneniia [Influence of physical condition individual norm and zone of functional optimum for work in extreme conditions]. Slobozhans'kij naukovo-sportivnij visnik, 2011;3:123-128. (in Russian)

3. Azhippo AIu, Puhach YI, Druz VA, Piatisotskaia SS. Ontologiia teorii postroeniia kontrolia i ocenki urovnia fizicheskogo razvitiia i fizicheskogo sostoianiia [Ontology of control building and assessment of physical condition and physical level]. Kharkov: HDAFK; 2015. (in Russian)

4. Bokanova AF, Druz VA, Puhach YI. Obshchie principy postroeniia processa razvitiia samoorganizuiushchikhsia sistem [General principles of construction of self-organizing systems]. Gumanitarnij chasopis, 2016;2:82-88. (in Russian)

5. Ol'son G. Dinamicheskie analogi [Dynamic analogies], Moscow: Foreign literature; 1947. (in Russian)

6. Sedov LI. Metody podobiia i razmernosti $v$ mekhanike [Methods of similarity and dimension in mechanic], Moscow: Science; 1981. (in Russian)

7. Puhach YI. Osnovnye polozheniia postroeniia semanticheskogo prostranstva dlia uporiadochennogo predstavleniia rezul'tatov issledovaniia [Main principles of semantic space construction for ordered presentation pof research results]. XI Mezhdunarodnaia nauchnoprakticheskaia konferencii «B»deshchego v»prosi ot sveta na naukata» [XI International scientific-practical conference "Promising problems of world of science"]. Sofia: White City - B.G.; 2013;39. P. 5-13. (in Russian)

8. Tamarin PV. Unifikaciia i kodirovanie kachestvennykh i kolichestvennykh priznakov [Unification and coding of quantitative and qualitative attributes], Metody sovremennoj biologii, 1978;1:130-157. (in Russian)

9. Pul'kin SP. Vychislitel'naia matematika [Calculation mathematics], Moscow: Education; 1974. (in Russian)

10.Brejtman MIa. Klinicheskaia semiotika i differencial'naia diagnostika endokrinnykh zabolevanij [Clinical semiotic and differentiated diagnostic of endocrine diseases], Leningrad: Medicine; 1949. (in Russian)

11.Druz VA, Buren' NV, Puhach YI, Piatisotskaia SS. Obzornyj analiz po probleme «Teoretiko-metodologicheskie osnovy postroeniia sistemy massovogo kontrolia i ocenki urovnia fizicheskogo razvitiia, sostoianiia $\mathrm{i}$ fizicheskoj podgotovlennosti razlichnykh grupp naseleniia» [Analysis- review of problem "Theoretical-methodological principles of building of mass control system and assessment of different population strata physical condition and physical fitness], Kharkov: HDAFK; 2014. (in Russian)

12.Azhippo AIu, Dorofeeva TI, Puhach YI, Artemyeva GP, Nechitajlo MV, Druz VA. Norma, standarty i testy v strukture postroeniia monitoringa fizicheskogo razvitiia, fizicheskoj podgotovlennosti i fizicheskogo sostoianiia [Norm, standards and tests in structure of construction of physical condition and physical fitness monitoring]. Slobozhans'kij naukovosportivnij visnik, 2015;5 (49):13-23. (in Russian)

13.Druz VA. Sportivnaia trenirovka i organizm [Sport training and organism], Kiev: Health; 1976. (in Russian)

14.Druz VA, Omel'chenko MV, Omel'chenko DA. Osnovy tekhniki sprinterskogo bega [Principles of sprinter technique]. Slobozhans'kij naukovo-sportivnij visnik, 2015;3 (47):41-46. (in Russian)

15.Ponomarev IaA. Psikhologiia tvorchestva [Psychology of creativity], Moscow: Science; 1976. (in Russian)

16.Puankare Anri. O nauke [About science], Moscow: Science; 1983. (in Russian)

17.Suorc KIE. Neobyknovennaia fizika obyknovennykh iavlenij [Unusual physics of usual phenomena], Moscow: Science; 1986. (in Russian)

18.Van Sin' Na. Sovershenstvovanie tekhniki vypolneniia sorevnovatel'nykh uprazhnenij kvalificirovannykh sportsmenov $v$ pauerliftinge. Kand. Diss. [Perfection of fulfilled exercises' technique of elite sportsmen in powerlifting. Cand. Diss], Kharkov; 2012. (in Russian)

19.Gorban' AN, Khlebopros RG, Demon Darvina. Ideia optimal'nosti $i$ estestvennyj otbor [Idea of optimality and natural selection], Moscow: Science; 1988. (in Russian)

20.Samarin MS. Vol't, Amper, Om i drugie edinicy fizicheskikh velichin v tekhnike sviazi [Volt, Ampere, Ohm and other units of physical values in communication], Moscow: Radio and Communications; 1988. (in Russian)

21.Adyrkhaev SG. Modern technology of physical education of disabled students in conditions of inclusive education. Pedagogics, psychology, medical-biological problems of physical training and sports, 2016;1:4-12. doi:10.15561/18189172.2016.0101

22.Al-Hariri MT, Al-Hattami AA. Utilization of internet by health colleges students at the University of Dammam. Journal of Taibah University Medical Sciences. 2015;10(1):66-73.

23.Bliznevsky AA, Kudryavtsev MD, Iermakov SS, Jagiello W. Formation of active-effective attitude of 12-13 years' judo athletes to sports functioning in competition period. Archives of Budo, 2016; 12: 101-115.

24.Buśko K, Staniak Z, Szark-Eckardt M, Nikolaidis PT, Mazur-Rózycka J, Łach P, . . Górski M. Measuring the force of punches and kicks among combat sport athletes using a modified punching bag with an embedded accelerometer. Acta of Bioengineering and Biomechanics, 2016; 18(1): 47- 
54. doi:10.5277/ABB-00304-2015-02

25.Erman KA, Şahan A, Balci YK. The Vocational Maturity of School of Physical Education and Sports Students. Procedia - Social and Behavioral Sciences. 2015 Feb;174:2380-2383.

26.Franco E, Coterón J, Martínez HA, Brito J. Perfiles motivacionales en estudiantes de educación física de tres países y su relación con la actividad física. Suma Psicológica [Internet]. 2016 Aug [cited 2016 Dec 22]; Available from: http://linkinghub.elsevier.com/retrieve/pii/ S0121438116300066

27.Gaskov AV, Kuzmin AV, Kudryavtsev DM, Iermakov SS. Successfulness of general and special physical qualities' development on different stage of students-boxers' training. Physical Education of Students, 2016;1:4-11. doi:10.15561/20755279.2016.0101

28.Holm-Hadulla RM, Koutsoukou-Argyraki A. Mental health of students in a globalized world: Prevalence of complaints and disorders, methods and effectivity of counseling, structure of mental health services for students. Mental Health \& Prevention. 2015;3(1-2):1-4.

29.Iermakov SS, Arziutov GN, Jagiello W. Quick training of students to judo techniques. Archives of Budo, 2016; 12: 1524.

30.Iermakov SS, Podrigalo LV, Jagiełło W. Hand-grip strength as an indicator for predicting the success in martial arts athletes. Archives of Budo, 2016; 12: 179-186.

31.Ilchenko SS. Motor and sport components in hierarchy of non physical culture profile pedagogic specialties students leisure. Pedagogics, psychology, medical-biological problems of physical training and sports, 2016;5:33-37. doi:10.15561/18189172.2016.0505

32.Kochanowicz A, Kochanowicz K, Niespodziúski B, Mieszkowski J, Aschenbrenner P, Bielec G, Szark-Eckardt M. Maximal power of the lower limbs of youth gymnasts and biomechanical indicators of the forward handspring vault versus the sports result. Journal of Human Kinetics, 2016; 53(1): 33-40. doi:10.1515/hukin-2016-0008

33.Kopeikina EN, Drogomeretsky VV, Kondakov VL, Kovaleva MV, Iermakov SS. Modification of Harvard step-test for assessment of students' with health problems functional potentials. Physical Education of Students, 2016;4:44-50. doi:10.15561/20755279.2016.0405

34.Kostencka A, Szark-Eckardt M. The estimation of educational needs of physical education teachers in the light of the new educational program basis. Human Movement, 2010; 11(2): 200-210. doi:10.2478/v10038-010-0014-2

35.Kudryavtsev MD, Kramida IE, Iermakov SS. Influence of studying in higher educational establishment on students' harmful computer habits. Physical Education of Students, 2016;5:17-23. doi:10.15561/20755279.2016.0503

36.Marc R Lochbaum, Javan Jean-Noel, Zişan Kazak Çetinkalp, Felipe Andrés Vallejo-Reyes, Jose Mena-Campbell. 2 x 2 achievement goals profiles in chilean competitive and recreational athletes: a first look. Pedagogics, psychology, medical-biological problems of physical training and sports, 2016;1:41-46. doi:10.15561/18189172.2016.0106

37.Pang B, Soong H. Teachers' experiences in teaching Chinese Australian students in health and physical education. Teaching and Teacher Education. 2016 May;56:84-93.

38.Podrigalo LV, Iermakov SS, Alekseev AF, Rovnaya OA. Studying of interconnections of morphological functional indicators of students, who practice martial arts. Physical Education of Students, 2016;1:64-70. doi:10.15561/20755279.2016.0109

39.Skead NK, Rogers SL. Running to well-being: A comparative study on the impact of exercise on the physical and mental health of law and psychology students. International Journal of Law and Psychiatry. 2016;49:66-74.

\section{Information about the authors:}

Druz V.A.; http://orcid.org/0000-0002-4628-6791; valeriidruz@gmail.com; Kharkiv State Academy of Physical Culture; Klochkivcka 99, Kharkiv, 61058, Ukraine.

lermakov S.S. ; http://orcid.org/0000-0002-5039-4517; sportart@gmail.com ; Kazimierz Wielki University ; Sport str. 2, of.209, 85064 Bydgoszcz, Poland.

Artemyeva G.P.; http://orcid.org/0000-0003-3121-2754; art gal.67@mail.ru; Kharkiv State Academy of Physical Culture; Klochkivcka, 99, Kharkiv, 61058, Ukraine.

Puhach Y.I.; http://orcid.org/0000-0001-5460-772X; sanadruz@gmail.com; Kharkiv State Academy of Physical Culture; Klochkivcka, 99, Kharkiv, 61058, Ukraine.

Muszkieta R.; http://orcid.org/0000-0001-6057-1583; radek.muszkieta@gmail.com; Uniwersytet Mikołaja Kopernika w Toruniu; Jurija Gagarina 11, 87-100 Toruń, Poland.

Cite this article as: Druz V.A, Iermakov S.S.,Artemyeva GP., PuhachYI, Muszkieta R. Individualization factors of students'physical education at modern stage of its realization. Physical education of students, 2017;1:10-16. doi:10.15561/20755279.2017.0102

The electronic version of this article is the complete one and can be found online at: http://www.sportedu.org.ua/index.php/PES/issue/archive

This is an Open Access article distributed under the terms of the Creative Commons Attribution License, which permits unrestricted use, distribution, and reproduction in any medium, provided the original work is properly cited (http://creativecommons.org/licenses/by/4.0/deed.en).

Received: 26.12.2016

Accepted: 21.01.2017; Published: 10.02.2017 